\title{
PROMOSI JABATAN DAN LINGKUNGAN KERJA NON FISIK DAMPAKNYA TERHADAP KINERJA KARYAWAN PADA GOLDEN TULIP BAY VIEW HOTEL \& CONVENTION BALI KUTA SELATAN BADUNG
}

\author{
Ni Made Gunastri* I Gusti Gede Oka Pradnyana \\ STIMI "Handayani”, Denpasar, Bali \\ *E-Mail: gunastri2015@gmail.com
}

\begin{abstract}
In order to face the business world that is full of competition, a company leader needs to do any efforts to look for a new paradigm and to define his business strategy, so the business can still survive, flourish and develop, while it is also expected to keep creating a conducive working environment. In general, once a person has been accepted, placed and employed by a company, then the next duty of a manager is to evaluate his or her performance. To set this policy later means whether that employee will be promoted, demoted and or got a remuneration. A promotion contributes to an important role for each of employee and even it becomes something that they always wait for. With this job promotion, it means there is a belief and acknowledgement related to the abilities and proficiency of the employees to occupy a higher level of position.

This research is aimed to 1) test and analyze the impacts of job promotion on the performance of employees at Golden Tulip Bay View Hotel \& Convention Bali; 2) test and analyze the impacts of non-physics working environment at Golden Tulip Bay View Hotel \& Convention Bali; 3) test and analyze the influences of job promotion and non-physical job environment on the employees working at Golden Tulip Bay View Hotel \& Convention Bali. This research used a survey designed to include respondents in overall 88 hotel employees. The samples were taken by using probability sampling technique that was called proportionate stratified random sampling. The test of hypothesis used was a multiple linear regression analysis with a data analysis entirely had been processed through SPSS version 17.0 program.

The first hypothesis result shown that the job promotion had positively and significantly influenced on the performance of employees with $t$ value counted was 4.249 and with significant level of 0.000. The second hypothesis described that the non-physical job environment had positively and significantly influenced to the performance of employees with t value counted was 5.550 and significant level of 0.000 that was smaller than 0.05. By looking at the standardized coefficient beta, the job promotion variable has taken into 0.395 and for the non-physical job environment variable was 0.423, so then it can be concluded that the non-physical job environment had a dominant influence on the performance of employees. This has been supported by the third hypothesis examination shown that both of the job promotions and non-physical job environment simultaneously had been influencing a positive and significant value on the performance of employees, as it seemed from the F value counted; it broke into 49.648 and with significant level of 0.000.
\end{abstract}

Keywords: job promotion, non-physical job environment, performance of the employees.

\begin{abstract}
Abstrak
Menghadapi dunia bisnis yang penuh dengan persaingan, maka pimpinan perusahaan di tuntut untuk selalu berusaha mencari paradigma baru dan meredifinisikan strategi bisnisnya supaya tetap survice, maju dan berkembang, disamping menciptakan kondisi kerja yang kondusif. Umumnya setiap perusahaan setelah karyawan diterima, ditempatkan dan dipekerjakan, maka tugas seorang manajer selanjutnya melakukan penilaian terhadap kinerja karyawan. Menetapkan kebijaksanaan ini berarti apakah seorang karyawan akan dipromosikan, didemosikan dan atau balas jasanya di naikkan. Promosi memberikan peran penting bagi setiap karyawan bahkan menjadi idaman yang selalu dinanti-nantikan. Dengan promosi berarti ada kepercayaan dan pengakuan mengenai kemampuan serta kecakapan karyawan bersangkutan untuk menduduki suatu jabatan yang lebih tinggi.

Tujuan penelitian adalah 1). Menguji dan menganalisis pengaruh promosi jabatan terhadap kinerja karya-
\end{abstract}


wan pada Golden Tulip Bay View Hotel \& Convention Bali.2). Menguji dan menganalisis pengaruh lingkungan kerja non fisik terhadap kinerja karyawan pada Golden Tulip Bay Vew Hotel \& Convention Bali.3). Menguji dan menganalisis pengaruh promosi jabatan dan lingkungan kerja non fisik terhadap kin Golden Tulip Bay View Hotel \& Convention Bali. Penelitian ini menggunakan desain survey dengan responden karyawan Golden Tulip Bay View Hotel \& Convention Bali sebanyak 88 orang. Selanjutnya sampel yang diambil dengan teknik probability sampling yakni proportionate stratified random sampling. Pengujian hipotesis menggunakan analisis regresi linier berganda dan pengolahan data sepenuhnya menggunakan bantuan program SPSS versi 17.0

Hasil pengujian hipotesis pertama menunjukkan bahwa promosi jabatan berpengaruh positif signifikan terhadap kinerja karyawan dengan nilai t hitung 4,249 dan tingkat signifikansi sebesar 0,000 hipotesis kedua lingkungan kerja non fisik berpengaruh positif signifikan terhadap kinerja karyawan dengan nilai $t$ hitung diperoleh 4,550 dan tingkat signifikansi 0,000 yang jauh lebih kecil dari 0,05. Dilihat dari standardized coefficient beta dimana untuk variabel promosi jabatan besarnya 0,395 dan untuk variabel lingkungan kerja non fisik sebesar 0,423 maka dapat disimpulkan bahwa variabel lingkungan kerja non fisik yang berpengaruh dominan terhadap kinerja karyawan dan pengujian hipotesis ketiga promosi jabatan dan lingkungan kerja non fisik secara simultan berpengaruh positif signifikan terhadap kinerja karyawan dilihat dari nilai $\mathrm{F}$ hitung yang diperoleh sebesar 49,648 dengan signifikansi 0,000

\section{Kata Kunci: skeptisme profesional, independensi, kompetensi, etika, role stress, kualitas audit}

\section{PENDAHULUAN}

Di era globalisasi dewasa ini banyak muncul perusahaan-perusahaan baik yang berskala nasional maupun internasional, setiap badan usaha apapun bentuknya selalu menempatkan diri sebaik-baiknya agar tetap dapat mempertahankan hidupnya. Menghadapi dunia bisnis yang penuh dengan persaingan, maka pimpinan perusahaan di tuntut untuk selalu berusaha mencari paradigma baru dan meredifinisikan strategi bisnisnya supaya tetap survice, maju dan berkembang, disamping itu menciptakan kondisi kerja yang kondusif sehingga motivasi kerja dan kinerja karyawan semakin tinggi.

Sumber daya manusia merupakan salah satu penentu keberhasilan perusahaan karena peran sumber daya manusia sebagai asset berharga adalah merencanakan, melaksanakan serta mengendalikan berbagai kegiatan operasional perusahaan sehingga SDM harus diperhatikan dalam melaksanakan fungsi -fungsi perusahaan untuk memperoleh keuntungan dan menjaga eksistensi perusahaan serta mampu meningkatkan kualitas pelayanan kepada konsumen disamping proses produksi. Permasalahan yang muncul ketika salah dalam mengelola sumber daya manusia adalah penurunan kinerja karyawan. Kinerja karyawan memiliki peranan penting bagi perusahaan, apabila kinerja yang ditampilkan karyawan rendah maka akan mengakibatkan perusahaan dalam mencapai tujuan menjadi terhambat (Ariana dkk, 2013). Kinerja adalah pencapaian hasil kerja karyawan berdasarkan kualitas maupun kuantitas sebagai prestasi kerja dalam periode waktu tertentu yang disesuaikan dengan tugas dan tanggung jawabnya (Mangkunegara, (2012: 9). Umumnya setiap perusahaan setelah karyawan diterima, ditempatkan dan dipekerjakan, maka tugas seorang manajer selanjutnya melakukan penilaian terhadap kinerja karyawan. Menetapkan kebijakanaan ini berarti apakah seorang karyawan akan dipromosikan, didemosikan dan atau balas jasanya di naikkan. Promosi memberikan peran penting bagi setiap karyawan bahkan menjadi idaman yang selalu dinanti-nantikan karena dengan promosi berarti ada kepercayaan dan pengakuan mengenai kemampuan serta kecakapan karyawan bersangkutan untuk menduduki suatu jabatan yang lebih tinggi.

Salah satu cara yang dapat dilakukan untuk meningkatkan kinerja karyawan adalah promosi jabatan. Menurut Hasibuan (2002) mengatakan bahwa "karyawan yang dipromosikan pada jabatan yang tepat dalam bekerja dapat semakin meningkatkan kinerja yang dihasilkan".Sementara Siagian (2005:169) dikatakan promosi jabatan adalah perpindahan karyawan dari satu jabatan/ tempat kepada jabatan/tempat lain yang lebih tinggi serta diikuti oleh tugas, tanggung jawab dan wewenang yang lebih tinggi dari jabatan yang diduduki sebelumnya. Dengan demikian promosi akan memberikan status sosial, wewenang (Authority), tanggung jawab (Responbility), serta penghasilan (Outcome) yang semakin besar bagi karyawan. Bila ada kesempatan bagi karyawan dipromosikan berdasarkan asas keadilan dan objekyifitas, karyawan akan terdorong bekerja lebih giat, bersemangat, disiplin, dan berprestasi kerja sehingga sasaran perusahaan secara optimal dapat dicapai (Hasibuan, 2007:107). Seperti pada hasil penelitian yang dilakukan oleh Mugabe (2015) dijelaskan bahwa promosi jabatan berpengaruh positif dan signifikan terhadap kinerja karyawan. Penelitian senada juga dilakukan oleh Navrathin Datu Sabar (2017) menyimpulkan bahwa“promosi jabatan memiliki pengaruh positif signifikan terhadap kinerja pegawai pada kantor wilayah direktorat jenderal perbendaharaan Sulawesi Utara". Sebaliknya jika kesempatan untuk dipromosikan relatif kecil/tidak ada maka gairah kerja, semangat kerja, disiplin kerja, dan kinerja kerja karyawan akan menurun. 
Begitu besar peranan promosi karyawan maka sebaiknya manajer personalia suatu perusahaan harus menetapkan program promosi serta menginformasikannya kepada para karyawan secara terbuka, baik tentang asas, dasar, jenis, persyaratan, maupun metode penilaian karyawan yang akan dilakukan dalam perusahaan. Jika hal ini dapat dilakukan dengan baik, akan menjadi motivasi bagi karyawan untuk bekerja sungguh-sungguh. Promosi jabatan dilakukan di dalam perusahaan juga mempunyai tujuan memberikan kesempatan kepada karyawan untuk mengembangkan kreativitas dan inovasinya yang lebih baik demi keuntungan optimal perusahaan, selain itu untuk menambah dan memperluas pengetahuan serta pengalaman kerja para karyawan, dan ini merupakan daya dorong karyawan untuk meningkatkan kinerjanya. disamping metetapkan promosi jabatan hal yang tidak kalah pentingnya saat ini untuk mempertahankan bisnis adalah dengan memperhatikan faktor lain yang dapat mempengaruhi kinerja karyawan adalah lingkungan kerja non fisik karyawan. Sebagaimana hasil penelitian yang dilakukan oleh Muhammad Kamif dkk (2016) menjelaskan bahwa lingkungan kerja non fisik berpengaruh signifikan terhadap kinerja karyawan. Penelitian sejenis oleh Rachmawati, Intan (2015) dan Darmawan (2011) juga menjelaskan bahwa lingkungan kerja non fisik berpengaruh positif dan signifikan terhadap kinerja karyawan.

Lingkungan kerja non fisik merupakan lingkungan kerja yang hanya dapat dirasakan oleh karyawan, dimana lingkungan kerja non fisik yang baik dapat memberikan perasaan aman dan puas kepada karyawan sehingga dapat mempengaruhi perilaku karyawan kearah positif sebagaimana diharapkan oleh organisasi/perusahaan. Menurut Wursanto (2003) "tugas seorang pimpinan organisasi adalah menciptakan suasana kerja yang harmonis dengan menciptakan human relations sebaik-baiknya". Karena itulah maka pimpinan menjadi faktor yang dapat menciptakan lingkungan kerja non fisik yang baik dalam lingkup organisasi. Dengan lingkungan kerja non fisik yang baik, diharapkan para karyawan dapat bekerja dengan baik dan merasa senang melakukan tugas yang diembannya serta saling menghargai hak dan kewajiban sesama karyawan dan pada gilirannya dapat menumbuhkan kerjasama yang solid.

Golden Tulip Bay View Hotel \& Convention Bali yang bergerak dibidang jasa perhotelan, sangat mengandalkan tenaga kerja untuk melakukan kegiatan operasionalnya. Hasil survey awal dan juga hasil wawancara dengan beberapa karyawannya menjelaskan bahwa karyawan yang di promosikan adalah sebagian besar dari karyawan daily worker (DW) menjadi staff dengan berdasarkan penilaian kinerja karyawan yang bersangkutan. Hal ini dilakukan karena memang sebagian besar karyawan yang bekerja pada hotel ini adalah bekerja sebagai daily worker (DW) atau pekerja harian lepas. Ada beberapa karyawan merasa tidak puas akan program promosi yang dilakukan pihak manajemen hotel karena tidak dilakukan berdasarkan asas keadilan. Penilaian karyawan yang di promosikan masih berbau pilih kasih atau like and dislike, Keadaan ini mengindikasikan pola hubungan antara karyawan DW dengan pihak atasan mereka kurang baik.

Sementara pihak manajemen juga telah menetapkan peraturan mengenai jangka waktu pelaksanaan program promosi jabatan setiap 6 (enam) bulan sekali, namun dalam kenyataannya pelaksanaan program promosi jabatan dilakukan setiap 1 (satu) tahun sekali. Sebagai dampaknya, telah menimbulkan kehilangan kreatifitas dikalangan karyawan dalam bekerja serta kurang optimal dalam bekerja yang ditunjukkan oleh adanya jumlah guest complain baik pada bagian Mechanical maupun pada bagian Service Related Problem. Kondisi ini mencerminkan adanya masalah terkait dengan promosi jabatan dan perlunya menciptakan lingkungan kerja non fisik yang baik sehingga karyawan dapat menghasilkan kerja yang baik pula.

Berdasarkan latar belakang masalah, maka yang menjadi pokok permasalahan dalam penelitian ini adalah, Apakah promosi jabatan mempengaruhi kinerja karyawan pada Golden Tulip Bay View Hotel \& Convention Bali?, Apakah lingkungan kerja non fisik mempengaruhi kinerja karyawan pada Golden Tulip Bay View Hotel \& Convention Bali?, Apakah promosi jabatan dan lingkungan kerja non fisik mempengaruhi kinerja karyawan pada Golden Tulip Bay View Hotel \& Convention Bali?

Berdasarkan pemaparan latar belakang dan masalah dilakukannya penelitian ini, terdapat beberapa tujuan yang menjadi acuan penelitian ini dilakukan, terdapat beberapa tujuan dalam melakukan penelitian ini seperti; Menguji dan menganalisis pengaruh promosi jabatan terhadap kinerja karyawan pada Golden Tulip Bay View Hotel \& Convention Bali, Menguji dan menganalisis pengaruh lingkungan kerja non fisik terhadap kinerja karyawan pada Golden Tulip Bay Vew Hotel \& Convention Bali, Menguji dan menganalisis pengaruh promosi jabatan dan lingkungan kerja non fisik terhadap kinerja karyawan pada Golden Tulip Bay View Hotel \& Convention Bali.

\section{TINJAUAN PUSTAKA}

\section{A. Tinjauan Pustaka}

\section{Pengertian Promosi Jabatan}

Manajemen bukan hanya memperhatikan kepentingan perusahaan tapi juga harus memperhatikan kepentingan karyawannya. Salah satunya yakni dengan melakukan promosi jabatan. Menurut Hasibuan (2007:18) mengemukkan "Promosi adalah perpindahan yang memperbesar autority dan responbility ke jabatan yang lebih tinggi 
didalam suatu organisasi sehingga kewajiban hak, status dan penghasilan juga lebih besar". Sedangkan Rivai (2004:211) menyebutkan "Promosi adalah apabila seorang karyawan dipindahkan dari satu pekerjaan ke pekerjaan lain yang lebih tinngi dalam pembayaran, tanggung jawab dan level. Umumnya diberikan sebagai penghargaan, hadiah (reward system) atas usaha dan prestasinya dimasa lampau". Selanjutnya Siagian (2005:169)"Promosi adalah apabila seseorang dari satu pekerjaan dipindahkan ke pekerjaan lain yang tanggung jawabnya lebih besar, tingkatan dalam hierarki jabatan lebih tinggi dan penghasilannya pun lebih besar".

Dari pengertian di atas dapat dikatakan bahwa promosi jabatan adalah perpindahan seorang karyawan dari suatu bidang pekerjaan kebidang yang lain, yang diikuti oleh naiknya tanggung jawab dan juga diikuti oleh naiknya penghasilan. Dengan diberlakukannya promosi jabatan dalam perusahaan akan membuat setiap karyawan merasa termotivasi dan merasakan bahwa kemampuannya dipercayai oleh perusahaan. Adapun indikator promosi jabatan yang dipergunakan dari pendapat Nitisemito (2002: 199) seperti: 1). Kejujuran, 2). Loyalitas 3). Tingkat pendidikan 4). Pengalaman Kerja, 5) Prestasi kerja dan . 6) Keadilan.

\section{Asas-asas Promosi jabatan}

Asas promosi jabatan harus dituangkan dalam program promosi secara jelas sehingga karyawan mengetahui dan perusahaan mempunyai pegangan untuk mempromosikan karyawan. Menurut Hasibuan (2007:108) menyebutkan 3 (tiga) asas promosi jabatan sebagai berikut:

a) Kepercayaan artinya promosi hendaknya berdasarkan pada kepercayaan atau keyakinan mengenai kejujuran, kemampuan, dan kecakapan karyawan bersangkutan dalam melaksanakan tugas-tugasnya dengan baik pada jabatan tersebut. Karyawan baru akan dipromosikan, jika karyawan itu menunjukkan kejujuran, kemampuan dan keakapannya dalam memangku jabatan.

b) Keadilan artinya promosi berasaskan keadilan, terhadap penilaian kejujuran, kemampuan, dan kecakapan semua karyawan. Penilaian harus jujur dan objektif tidak pilih kasih atau like and dislike. Karyawan yang mempunyai peringkat (ranking) terbaik hendaknya mendapat kesempatan pertama untuk dipromosikan tanpa melihat suku, golongan, dan keturunannya. Promosi yang berdasarkan keadilan akan menjadi alat motivasi bagi karyawan untuk meningkatkan prestasinya.

c) Formasi artinya promosi harus berasaskan kepada formasi yang ada, karena promosi karyawan hanya mungkin dilakukan jika ada formasi jabatan yang lowong. Untuk itu harus ada uraian perkerjaan/jabatan (job description) yang akan dilaksanakan karyawan. Jadi, promosi hendaknya disesuaikan dengan formasi jabatan yang ada di dalam perusahaan.

\section{Lingkungan Kerja Non Fisik}

Menurut Sedarmayanti (2001), “Lingkungan kerja non fisik adalah semua keadaan yang terjadi yang berkaitan dengan hubungan kerja, baik hubungan dengan atasan maupun hubungan sesama rekan kerja, ataupun hubungan dengan bawahan". Sementara itu, Wursanto (2003) menyebutnya sebagai lingkungan kerja psikis yang didefinisikan sebagai "sesuatu yang menyangkut segi psikis dari lingkungan kerja”. Berdasarkan pengertian tersebut, dapat dikatakan bahwa lingkungan kerja non fisik disebut juga lingkungan kerja psikis, yaitu keadaan di sekitar tempat kerja yang bersifat non fisik. Lingkungan kerja semacam ini tidak dapat ditangkap secara langsung dengan panca indera manusia, namun dapat dirasakan keberadaannya. Jadi, lingkungan kerja non fisik merupakan lingkungan kerja yang hanya dapat dirasakan oleh perasaan seperti: 1) adanya perasaan aman dari para pegawai dalam menjalankan tugasnya, 2) adanya loyalitas yang bersifat dua dimensi, 3) adanya perasaan puas di kalangan pegawai. Adapun indikator yang dipergunakan untuk variabel lingkungan kerja non fisik menurut Wursanto (2003) yaitu: 1). suasana kerja; 2). kesempatan mengembangkan karier; 3). perilaku adil dan obyektif; 4) hubungan antar individu, 5).rasa aman, 6). Sistem pemberian imbalan.

\section{Kinerja Karyawan}

Menurut Rivai (2009) mengemukakan pengertian Kinerja adalah hasil kerja secara kualitas dan kuantitas yang dicapai oleh seorang karyawan dalam melaksanakan tugasnya sesuai dengan tanggungjawab yang diberikannya. Sementara Amstrong dan Baron dalam Wibowo (2010:7) kinerja merupakan hasil pekerjaan yang mempunyai hubungan kuat dengan tujuan strategis organisasi, kepuasan konsumen, dan memberikan kontribusi pada ekonomi. Berdasarkan uraian dari pendapat para ahli di atas, maka dapat dikatakan kinerja adalah hasil kerja yang dicapai oleh seseorang dalam melaksanakan tugasnya sesuai dengan standard an kinerja yang telah ditetapkan untuk pekerjaan itu. Adapun indikator yang dipergunakan menurut Mangkunegara (2010) adalah a). kualitas kerja, b). kuantitas kerja, c). pelaksanaan tugas , d). tanggung jawab, e). kerjasama, f). inisiatif.

\section{Pengaruh Promosi Jabatan Terhadap Kinerja Karyawan}

Promosi jabatan mempunyai peran penting dalam 
peningkatan kinerja pegawai karena promosi jabatan merupakan kesempatan untuk berkembang dan maju yang diberikan perusahaan agar dapat mendorong karyawan bekerja lebih baik atau lebih bersemangat dalam melakukan suatu pekerjaan dalam lingkungan perusahaan. Dengan adanya peluang promosi, pegawai dapat merasa lebih dihargai, diperhatikan, dibutuhkan dan diakui kemampuan kerjanya oleh manajemen perusahaan sehingga mereka akan menghasilkan output yang baik serta akan mempertinggi kinerjanya pada perusahaan sehingga perusahaan dapat mencapai tujuan yang telah ditetapkan oleh perusahaan tersebut. Manullang (2006:165) menjelaskan "promosi yang dilakukan oleh suatu perusahaan untuk mempertinggi kinerja karyawan". Jika promosi jabatan direalisasikan kepada karyawan yang berprestasi tinggi, maka akan menimbulkan semangat kerja yang tinggi dan membawa pengaruh pada produktivitas karyawan. Para peneliti sebelumnya Navrathin dkk (2017) dan Pahlevi Mugabe (2015) melalui bukti empirisnya mendukung bahwa promosi jabatan berpengaruh positif dan signifikan terhadap kinerja pegawai.

\section{Pengaruh Lingkungan Kerja Non Fisik Terhadap Kinerja Karyawan}

Lingkungan kerja non fisik memegang peran penting dalam meningkatkan kinerja karyawan karena dengan terciptanya kondisi lingkungan kerja non fisik yang kondusif maka sikap karyawan akan saling menghargai saat berbeda pendapat, tingginya kerjasama antar tingkat atasan maupun bawahan, terciptanya suasana kekeluargaan, komunikasi yang baik., karyawan akan dapat bekerja dengan merasa aman dan akan dapat meningkatkan kinerja karyawan tersebut. Hasil penelitian sebelumnya oleh Intan Kumalasari (2015) dan R Damanik (2015) menyimpulan bahwa ;lingkungan kerja non fisik bepengaruh positif dan signifikan terhadap kinerja karyawan.

\section{B. HIPOTESIS}

Dalam penelitian ini dapat dirumuskan beberapa hipotesis sebagtai berikut:

1) Promosi jabatan berpengaruh signifikan terhadap kinerja karyawan Golden Tulip Bay View Hotel \& Convention Bali

2) Lingkungan kerja non fisik berpengaruh signifikan terhadap kinerja karyawan Golden Tulip Bay View Hotel \& Convention Bali

3) Promosi jabatan dan lingkungan kerja non fisik berpengaruh signifikan terhadap kinerja karyawan Golden Tulip Bay View Hotel \& Convention Bali

\section{Kerangka Pemikiran}

Berdasarkan telaah pustaka dan temuan-temuan sebelumnya dapat diangkat sebuah model konseptual seperti yang disajikan dalam gambar berikut:

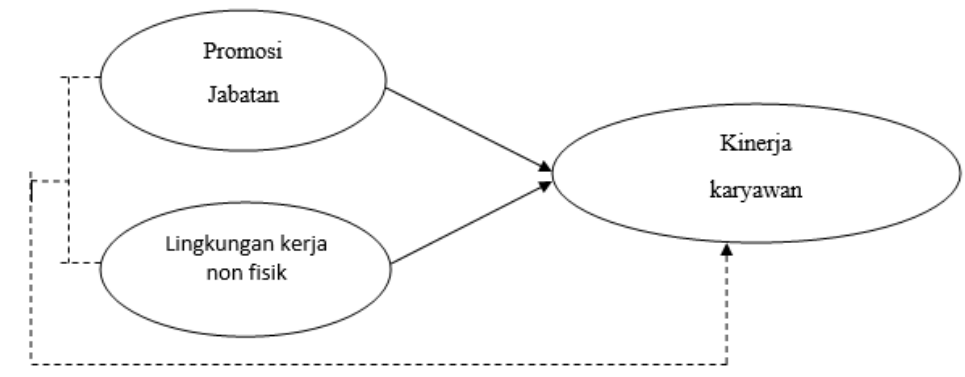

Gambar 1: Kerangka Pemikiran Penelitian

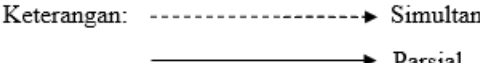

\section{III.METODE PENELITIAN}

\section{A. Subyek Dan Obyek Penelitian}

Penelitian ini dilakukan pada Golden Tulip Bay View Hotel \& Convention Bali yang berlokasi di jalan Uluwatu Banjar Giri Dharma Ungasan Kuta Selatan Badung. Sebagai obyek atau variabel dalam penelitian ini adalah promosi jabatan, lingkungan kerja non fisik dan kinerja karyawan.

\section{B. Definisi Operasional}

Berdasarkan teori dan kerangka pemikiran di atas terdapat 3 (tiga) variabel yang diteliti yaitu:

1) Promosi jabatan (X1) dimaksud perpindahan karyawan Golden Tuilip Bay View Hotel \& Convention dari yang berstatus daily worker (DW) ke karyawan yang berstatus staff dengan kewajiban dan hak serta penghasilan yang lebih tinggi.

2) Lingkungan Kerja Non Fisik (X2) dimaksud suatu keadaan yang terjadi berkaitan dengan hubungan kerja karyawan Golden Tulip Bay 
View Hotel \& Convention Bali baik hubungan dengan atasan maupun hubungan sesama rekan karyawan ataupun hubungan dengan karyawan bawahan

3) Kinerja karyawan (Y) merupakan hasil kerja yang dicapai oleh karyawan Golden Tulip Bay View Hotel \& Convention Bali dalam melaksanakan tugasnya sesuai dengan standar dan kinerja yang ditetapkan untuk pekerjaan itu.

\section{Sumber Dan Jenis Data}

Sumber data mempergunakan data primer dan jenis data kuantitatif yang berupa jumlah karyawan hotel, skor jawaban responden dan jenis data kualitatif seperti sejarah dan informasi struktur organisasi hotel.

\section{Populasi, Sampel Dan Teknik Sampling}

Populasi dalam penelitian ini berjumlah 127 orang karyawan yang memiliki masa kerja minimal satu tahun dan terdistribusi di 8 (delapan) departemen. Selanjutnya sampel yang diambil dengan teknik proportionate stratified random sampling. Sampel di ambil dari populasi yang terdiri dari karyawan DW dan karyawan tetap dan jumlah responden untuk masing-masing departemen diambil secara proposional.

Adapun perhitungan sampel dilakukan dengan menggunakan rumus Slovin, ((Umar, 2003:146): sehingga jumlah sampel yang dijadikan sebagai responden dalam penelitian ini sebanyak 88 orang karyawan.

\section{E. Teknik Pengumpulan Data}

Data yang diperlukan dalam penelitian ini pada adalah data tentang persepsi karyawan yang dituangkan dalam kuesioner, sehingga pengumpulan data dalam penelitian ini dilakukan melalui beberapa cara yaitu:

1) Kuesioner yaitu metode pengumpulan data primer dengan menggunakan seperangkat daftar pertanyaan mengenai variabel-variabel yang di ukur dengan menyediakan pilihan jawaban (bersifat tertutup). Skor jawaban responden yang di ukur dengan menggunakan skala likert dengan memberikan nilai 1, 2, 3, 4 dan 5 sehingga setiap skor yang diperoleh akan memiliki tingkat pengukuran ordinal. Selanjutnya dengan menggunakan metode MSI (Method Of Successive Interval maka data ordinal akan menjadi data dengan tipe interval. Untuk mendapatkan hasil penelitian yang valid dan reliabel maka instrument mutlak diuji dengan uji validitas dan uji reliabilitas sebelum disebarkan kepada responden sehingga diharapkan agar mampu mengukur apa yang ingin diukur dan dapat mengungkap data dari variabel-variabel yang diteliti secara tepat. Uji validitas dan uji reliabilitas kuesiomer diolah dengan bantuan program SPSS for windows versi 17.0

2) Dokumentasi yaitu suatu teknik pengumpulan data yang bersumber dari dokumen-dokumen yang ada pada hotel dan tentu yang berhubungan dengan masalah yang diteliti.

\section{F. Teknik Analisis Data}

Dalam penelitian ini menggunakan teknik analisis data statistik deskriptif dan regresi linier berganda serta uji hipotesis menggunakan uji $\mathrm{F}$ dan uji t. Dalam pengolahan data menggunakan alat bantu program SPSS for windows versi 17.0.

\section{IV.HASIL PENELITIAN DAN PEMBAHASAN}

\section{A. Uji Validitas dan Reliabilitas}

Uji validitas atau kesahihan digunakan untuk mengetahui seberapa tepat suatu alat ukur mampu melakukan fungsinya. Uji validitas kuesioner dalam penelitian ini diolah dengan bantuan program SPSS For Window versi 17.0. alat ukur yang dapat digunakan dalam pengujian validitas suatu kuesioner/instrumen adalah angka korelasi antara skor pernyataan dan skor keseluruhan pernyataan responden terhadap informasi dalam kuesioner (Triton, 2006). Dengan kriteria pengujian, jika nilai probabilitas atau $\mathrm{p}<\alpha=0,05$ dengan alat uji korelasi pearson maka koesioner valid untuk mengukur variable-variabel penelitian.

Berdasarkan uji validitas yang telah dilakukan terhadap ketiga variabel yaitu promosi jabatan $\left(\mathrm{X}_{1}\right)$, lingkungan kerja non fisik $\left(\mathrm{X}_{2}\right)$, dan Kinerja (Y) dapat diketahui bahwa keseluruhan butir pernyataan kuesioner variabel promosi jabatan (X1), lingkungan kerja non fisik (X2) dan kinerja (Y) adalah valid. Ini berarti keseluruhan butir pernyataan tersebut valid untuk mengukur variabel-variabel dalam penelitian ini.

Sementara uji reliabilitas digunakan untuk mengetahui konsistensi atau keteraturan hasil pengukuran suatu instrumen dari waktu ke waktu, sehingga bila alat ukur tersebut digunakan kembali menggunakan objek yang sama walaupun dengan waktu yang berbeda maka hasilnya akan tetap sama. (Triton, 2006). Pengujian reliabilitas kuesioner dalam penelitian ini diolah dengan bantuan program SPSS for windows versi 17.0 dengan melihat nilai Alpha $(\alpha)-$ Cronbach. Tingkat reliabilitas dengan menggunakan metode Alpha $(\alpha)=$ Cronbach diukur berdasarkan skala Alpha $(\alpha) 0$ sampai dengan 1 dan berdasarkan ukuran kemantapan alpha dapat diinterpretasikan bahwa ke tiga variabel yang diuji reliabel untuk mengukur variabel penelitian. 


\section{B. Deskripsi hasil Penelitian \\ 1) Deskripsi Variabel Promosi Jabatan}

Variabel promosi jabatan diukur melalui 6 butir pertanyaan dimana item 1 (satu) sampai dengan item 6 (enam) mempersepsikan 6 (enam) indikator yakni: kejujuran, loyalitas, tingkat pendidikan, pengalaman, inisiatif, keadilan. Hasil tanggapan responden terhadap promosi jabatan dapat dijelaskan bahwa loyalitas karyawan mendapatkan total nilai skor tertinggi yakni 386 dan yang terendah indikator tingkat pendidikan karyawan dengan total nilai skor 351. Sementara rata-rata total nilai skor untuk item 1 sampai item 6 adalah 4,03 yang terletak antara 3,41 $-4,20$ yang artinya promosi jabatan yang diterapkan termasuk dalam katagori baik.

\section{2) Deskripsi Variabel Lingkungan Kerja Non Fisik}

Variabel lingkungan kerja non fisik diukur melalui 6 butir pertanyaan dimana item 1 (satu) sampai dengan 6 (enam) mempersepsikan 6 (enam) indikator yakni : suasana kerja;. kesempatan mengembangkan karier; perilaku adil dan obyektif; hubungan antar individu,.rasa aman,dan sistem pemberian imbalan. Hasil tanggapan responden terhadap lingkungan kerja non fisik dapat dijelaskan bahwa kesempatan mengembangkan karier mendapatkan total nilai skor tertinggi yakni 396 dan yang terendah indikator perilaku adil dan obyektif dengan total nilai skor 365 . Sementara rata-rata total nilai skor untuk item 1 (satu) sampai item 6 (enam) adalah 4,30 yang terletak antara 4,21 - 5,00 yang artinya lingkungan kerja non fisik pada Golden Tulip Bay View Hotel \& Convention Bali termasuk dalam katagori sangat baik.

\section{3) Deskripsi Variabel Kinerja Karyawan}

Variabel kinerja karyawan diukur melalui 6 (enam) butir pertanyaan dimana item 1(satu) sampai dengan 6 (enam) mempersepsikan 6 (enam) indicator yakni:. kualitas kerja, kuantitas kerja, pelaksanaan tugas , tanggung jawab,. kerjasama, inisiatif. Hasil tanggapan responden terhadap kinerja karyawan dapat dijelaskan bahwa kerjasama mendapatkan total nilai skor tertinggi yakni 374 dan yang terendah indikator pelaksanaan tugas dengan total nilai skor 355. Sementara rata-rata total nilai skor untuk item 1 (satu) sampai item 6 (enam) adalah 4,14 yang terletak antara 3,41 - 4,20 yang artinya kinerja karyawan termasuk dalam katagori baik.

\section{Analisis Regresi Linier Berganda}

Sebelum model regresi digunakan untuk memprediksi atau meramalkan variabel kinerja karyawan, maka terlebih dahulu akan dilakukan pengujian asumsi klasik. Uji asumsi klasik bertujuan untuk mendapatkan model regresi linier berganda yang menghasilkan estimator linier tidak bias terbaik atau Best Linier Unbias estimator/ BLUE (Algifari, 2000), dimana uji tersebut meliputi Uji Normalitas, Uji Multikolinieritas, Uji Heteroskedasitas.

Berdasarkan hasil uji normalitas menunjukkan bahwa besarnya nilai Asymp Sig sebesar 0,587 lebih besar dari 0,05 sehingga dapat disimpulkan bahwa data yang digunakan dalam penelitian ini merupakan data yang berdistribusi normal. Pengujian multikolinearitas dilakukan dengan melihat hasil dari nilai tolerance di atas 0,1 dan nilai Variance Inflation Factor (VIF) di bawah 10 yang berarti tidak terdapat gejala multikolinearitas. Hasil uji multikolinearitas menunjukkan bahwa nilai tolerance variabel bebas berada di atas 0,1 dan nilai VIF berada di bawah 10 . Jadi dapat disimpulkan bahwa model tidak terdapat gejala multikolinearitas. Selanjutnya hasil pengujian Heteroskedasitas. menunjukkan regresi tidak mengandung gejala heteroskedastisitas. Dari analisis regresi linier berganda dengan pengolahan data melalui SPSS For Window versi 17.0 diperoleh hasil seperti yang ditunjukkan pada tabel berikut ini:

\section{Tabel 1 Coefficients}

\begin{tabular}{|c|c|c|c|c|c|c|c|}
\hline \multirow[b]{2}{*}{ Model } & \multicolumn{2}{|c|}{ Unstandardized Coefficients } & \multirow{2}{*}{$\begin{array}{c}\text { Standardized } \\
\text { Coefficients }\end{array}$} & \multirow[b]{2}{*}{$\mathrm{t}$} & \multirow[b]{2}{*}{ Sig. } & \multicolumn{2}{|c|}{$\begin{array}{c}\text { Collinearity } \\
\text { Statistics }\end{array}$} \\
\hline & $B$ & Std. Error & & & & Tolerance & VIF \\
\hline (Constant) & 5.780 & 1.933 & & 2.991 & .004 & & \\
\hline Promosi Jabatan & .392 & .092 & 395 & 4.249 & .000 & .628 & 1.593 \\
\hline $\begin{array}{l}\text { Lingkungan Kerja non } \\
\text { Fisik }\end{array}$ & 372 & .082 & .423 & 4.550 & .000 & .628 & 1.593 \\
\hline
\end{tabular}

Sumber: Hasil analisis

Berdasarkan data pada tabel di atas maka persamaan regresi linier berganda dapat dinyatakan: $\mathrm{Y}=5,780+0,392 \mathrm{X}_{1}+0,372 \mathrm{X}_{2}+\mathrm{e}$

Yang dapat djelaskan sebagai berikut:

1) Koefisien konstata sebesar 5,780 menunjukkan bahawa jika promosi jabatan dan lingkungan kerja non fisik konstan maka koefisien kinerja karyawan Golden Tulip Bay View Hotel \& Convention Bali adalah sebesar 5,780.

2) Nilai koefisien regresi promosi jabatan $\left(X_{1}\right)$ atau $\mathrm{b} 1=0,392$ mempunyai arti jika terjadi kenaikan promosi jabatan sebesar 1 satuan dengan asumsi lingkungan kerja non fisik $\left(\mathrm{X}_{2}\right)$ konstan, maka kinerja karyawan akan 
mengalami kenaikan sebesar 0.392 satuan dan sebaliknya. Dengan demikian promosi jabatan $\left(\mathrm{X}_{1}\right)$ memiliki pengaruh positif terhadap kinerja karyawan $(\mathrm{Y})$.

3) Nilai koefisien regresi lingkungan kerja non fisik $\left(\mathrm{X}_{2}\right)$ atau $\mathrm{b} 2=0,372$ mempunyai arti jika terjadi kenaikan lingungaan kerja non fisik 1 satuan dengan asumsi promosi jabatan $\left(\mathrm{X}_{1}\right)$ konstan, maka kinerja karyawan akan mengalami kenaikan sebesar 0,372 satuan dan sebaliknya. Dengan demikin lingkungan kerja non fisik $\left(\mathrm{X}_{2}\right)$ memiliki pengaruh positif terhadap kinerja karyawan (Y).

\section{Pengujian Hipotesis}

1) Pengaruh Promosi Jabatan dan Lingkungan Kerja Non Fisik Terhadap Kinerja Karyawa.

Pengujian hipotesis pertama ini dilakukan secara simultan (Uji F) dengan melihat nilai F-hitung pada tabel ANOVA berikut ini:

Tabel 2 ANOVA

\begin{tabular}{|c|c|c|c|c|c|c|}
\hline \multicolumn{2}{|c|}{ Model } & \multirow{2}{*}{\begin{tabular}{r|} 
Sum of Squares \\
446.696
\end{tabular}} & \multirow[t]{2}{*}{$\mathrm{df}$} & \multirow{2}{*}{\begin{tabular}{r|} 
Mean Square \\
223.348
\end{tabular}} & \multirow{2}{*}{\begin{tabular}{|l|}
$\mathrm{F}$ \\
49.648
\end{tabular}} & \multirow{2}{*}{$\frac{\text { Sig. }}{.000^{\mathrm{a}}}$} \\
\hline 1 & Regression & & & & & \\
\hline & Residual & 382.384 & 85 & 4.499 & & \\
\hline & Total & 829.080 & 87 & & & \\
\hline
\end{tabular}

Berdasarkan hasil uji $\mathrm{F}$ diperoleh nilai $\mathrm{F}$ sebesar 49,648 dan tingkat signifikansi $=0,000$ maka Ho ditolak dan $\mathrm{Hi}$ diterima. Ini berarti ada pengaruh dari Promosi Jabatan $\left(\mathrm{X}_{1}\right)$ dan Lingkungan Kerja Non Fisik $\left(\mathrm{X}_{2}\right)$ secara simultan terhadap kinerja karyawan Golden Tulip Bay View Hotel \& Convention Bali dapat dibuktikan.

\section{2) Pengaruh Promosi Jabatan Terhadap Kinerja Karyawan}

Pengujian hipotesis kedua dilakukan secara parsial (uji t) dengan melihat nilai t-hitung pada tabel coefficients diperoleh nilai $\mathrm{t}$ sebesar 4,249 dengan tingkat signifikansi 0,000 yang lebih kecil 0,005 maka Ho ditolak dan Hi diterima. Ini berarti Promosi Jabatan berpengaruh signifikan dan positif terhadap kinerja karyawan Golden Tulip Bay View Hotel \& Convention Bali dapat dibuktikan

\section{3) Pengaruh Lingkungan Keja Non Fisik Terhadap Kinerja Karyawan}

Pengujian Pengujian hipotesis ketiga dilakukan secara parsial (uji t) dengan melihat nilai t-hitung pada tabel coefficients diperoleh nilai t sebesar 4,550 dengan tingkat signifikansi 0,000 yang lebih kecil 0,05 maka Ho ditolak dan Hi diterima. Ini berarti lingkungan kerja non fisik berpengaruh signifikan dan positif terhadap kinerja karyawan Golden Tulip Bay View Hotel \& Convention Bali dapat dibuktikan.

\section{E. Pembahasan}

1) Deskripsi Variabel Promosi Jabatan, Lingkungan Kerja Non Fisik Dan Kinerja Karyawan.

Hasil analisis kuesioner terhadap 88 responden penelitian (rekapitulasi kuesioer selengkapnya pada lampiran 2) mengenai variabel promosi jabatan, lingkungan kerja fisik dan kinerja dapat mendeskripsikan tentang persepsi responden tentang promosi jabatan, lingkungan kerja fisik dan kinerja karyawan. Rata-rata jawaban responden untuk ke 6 (enan) pertanyaan/pernyataan tentang promosi jabatan menunjukkan skor rata-rata 4,03 yang terletak antara 3,41 - 4,20 yang artinya promosi jabatan termasuk kategori level baik dan lingkungan kerja non fisik menunjukkan skor rata-rata 4,30 yang terletak antara 4,2 - 4,50 yang artinya lingkungan kerja non fisik termasuk kategori level sangat baik. Sedangkan untuk kinerja karyawan rata-rata jawaban responden untuk ke 6 (enam) pertaanyaan/ pertanyaan menunjukkan skor rata-rata 4,14 yang terletak antara 3,41 - 4,20 yang artinya kinerja kaaryawan termasuk kategori level baik.

\section{2) Pengaruh Promosi Jabatan dan Lingkungan} Kerja Non Fisik Terhadap Kinerja Karyawan

Berdasarkan hasil penelitian, Promosi Jabatan dan Lingkungan Kerja Fisik secara simultan berpengaruh positif dan signifikan terhadap kinerja karyawan Golden Tulip Bay View Hotel \& Convention Bali, Hal ini sejalan dengan penelitian yang dilakukan oleh Pahlevi Mugabe (2015) bahwa promosi jabatan dan lingkungan kerja baik fisik maupun non fisik berpengaruh signifikan terhadap kinerja karyawan. Untuk mengoptimalkan kinerja karyawan promosi jabatan hendaknya direalisasikan kepada karyawan yang berprestasi tinggi, dan pihak manajemen mampu menciptakan lingkungan kerja non fisik baik yakni dengan menjalin hubungan kerja sama yang kondusif, komunikasi yang baik antara sesame karyawan dan atasan sehingga menimbulkan semangat kerja yang tinggi. Keadaan ini dapat meningkatkan produktivitas kerja para karyawan karena dengan diakuinya kemampuan kerja karyawan oleh manajemen, mereka akan 
menghasilkan output yang baik serta mempertinggi kinerjanya. Apa yang menjadi tujuan Golden Tulip Bay View Hotel \& Convention Bali dapat tercapai.

\section{3) Pengaruh Promosi Jabatan Terhadap Kinerja Karyawan}

Berdasarkan hasil penelitian promosi jabatan berpengaruh signifikan terhadap kinerja karyawan Golden Tulip Bay View Hotel \& Convention Bali. Hasil penelitian ini didukung oleh penelitian yang dilakukan oleh Navrathin dkk (2017), Pahlevi Mugabe (2015) . Promosi jabatan akan memberikan status sosial, wewenang, tanggung jawab dan penghasilan yang semakin besar sehingga banyak karyawan yang menginginkan untuk mendapatkan promosi jabatan. Jika promosi jabatan direalisasikan kepada karyawan mereka akan terdorong bekerja giat, bersemangat, berdisiplin yang berdampak pada kinerja yang baik. Ini berarti promosi jabatan sangat berpengaruh bagi kinerja karyawan.

\section{4) Pengaruh Lingkungan Kerja Non Fisik Terhadap Kinerja Karyawan}

Berdasarkan hasil penelitian terdapat pengaruh positif signifikan antara lingkungan kerja non fisik terhadap kinerja karyawan. Hal ini berarti semakin baik hubungan kerjasama antar tingkat atasan, bawahan maupun yang memiliki status jabatan yang sama, suasana kekeluargaan dan komunikasi yang semakin baik dikalangan karyawan maka akan mengakibatkan kinerja karyawan semakin tinggi pula. Temuan penelitian ini didukung oleh penelitian Intan Kumalasari (2015) dan R. Damanik (2015) menyimpulan bahwa ;lingkungan kerja non fisik bepengaruh positif dan signifikan terhadap kinerja karyawan.

\section{V) PENUTUP}

\section{A. Simpulan}

Berdasarkan hasil analisis dan pembahasan yang telah dilakukan maka dapat disimpulkan:

1) Dari hasil penelitian 88 responden tentang promosi jabatan, lingkungan kerja non fisik menunjukkan bahwa promosi jabatan dan lingkungan kerja non fisik termasuk dalam katagori /level sangat baik, sedangkan kinerja karyawan termasuk level baik.

2) Variabel promosi jabatan dan lingkungan kerja non fisik secara simultan berpengaruh positif dan signifikan terhadap kinerja karyawan Golden Tulip Bay View Hotel \& Convention Bali yang dapat dilihat dari perhitungan uji $\mathrm{F}$ dimana diperoleh hasil $F_{\text {hitung }}(49,648)$ dengan signifikansi 0,000 lebih kecil dari 0,05.

3) Selanjutnya secara parsial promosi jabatan dan lingkungan kerja non fisik berpengaruh positif dan signifikan terhadap kinerja karyawan Golden Tulip Bay View Hotel \& Convention Bali dapat dilihat dari perhitungan uji t dimana variabel promosi jabatan $t_{\text {hitung }}(4,249)$ dengan tingkat signifikansi 0,000 dan lingkungan kerja non fisik $\mathrm{t}$ hitung $(4,550)$ dengan tingkat signifikansi 0,000 yang lebih kecil dari 0,05 Dilihat dari standardized coefficient beta dimana untuk variabel promosi jabatan besarnya 0,395 dan untuk variabel lingkungan kerja non fisik sebesar 0,423 maka dapat disimpulkan bahwa variabel lingkungan kerja non fisik yang berpengaruh dominan terhadap kinerja karyawan

\section{B. Saran}

Berdasarkan simpulan yang telah diuraikan di atas, maka saran-saran yang dapat diberikan adalah sebagai berikut:

1) Bagi pihak manajemen hotel hendaknya lebih memperhatikan azas keadilan dalam melaksanakan program promosi jabatan meskipun telah diberikan motivasi atau dorongan yang kuat untuk menjadikan karyawannya lebih baik dalam meningkatkan kinerja.

2) Pihak manajemen hotel diharapkan untuk dapat lebih memperhatikan lingkungan kerja non fisik karena semakin baik hubungan kerjasama antar tingkat atasan, bawahan maupun yang memiliki status jabatan yang sama, suasana kekeluargaan dan komunikasi yang semakin baik dikalangan karyawan maka akan mengakibatkan kinerja karyawan semakin tinggi pula.

\section{DAFTAR PUSTAKA}

Ariana, I wayan Tresna dan I Gede Riana, 2013 Pengaruh Kepemimpinan, Kompensasi Dan Disiplin Kerja Terhadap Kinerja Karyawan pada Hotel Cendana Resort \& Spa Ubud Gianyar, E - Journal Manajemen Universitas Udayana 2 (1)

Algifari, 2000 Analisis Regresi, Teori, Kasus dan Solusi, Edisi 2. Penerbit BPEE, Yogyakarta

Budi, Triton Prawira, 2006 SPSS 13.0 Terapan Riset Statistik Parametrik, Yogyakarta: Penerbit Andi

Darmawan, 2011 Pengaruh Kompensasi dan Lingkungan Kerja Non Fisik Terhadap Disiplin dan Kinerja Karyawan Hotel Nikki Denpasar, Tesis Universitas Udayana, Denpasar Bali

Datu,Navrathin Sabar, Adolfina, Lucky O.H., Dotulong (2017) Pengaruh Promosi Jabatan Dan Mutasi Terhadap Kinerja Pegawai (Studi 
pada Pegawai Kantor Wilayah Direktorat Jenderal Perbendaharaan Provinsi Sulawesi Utara) Skripsi pada Jurusan Manajemen Fakultas Ekonomi Dan Bisnis, Universitas Sam Ratulangi

Hasibuan, Melayu SP, 2007 Manajemen Sumber Daya Manusia, Edisi Revisi, Jakarta, Bumi Aksara

Kumalasari,Putu, Intan, 2015 Pengaruh Kompensasi Dan Lingkungan Kerja Non Fisik Terhadap Kinerja Karyawan Pada Hotel Citadines Kuta Beach Bali. Skripsi Sekolah Ilmu Manajemen Indonesia Handayani Denpasar

Manullang, 2006, Manajemen Personalia, BPEE, Yogyakarta

Mugabe, Pahlevi (2015) Pengaruh Promosi Jabatan Dan Lingkungan Kerja Terhadap Kinerja Pegawai Kantor Pusat PT. Pelabuhan Indonesia I (Persero) Medan Skripsi pada Fakultas Ekonomi Dan Bisnis Universitas Sumatera Utara Medan

Mangkunegara, Anwar Prabu, 2010 Manajemen Sumber Daya Manusia Perusahaan, Remaja Rosda Karya, Bandung

Mangkunegara, Anwar Prabu, 2012 Evaluasi Kinerja Sumber Daya Manusia, Jakarta: PT

Refika Aditama

Nitisemito Alex, 2002 Manajemen Personalia: Manajemen Sumber Daya Manusia Ed 3, Ghalia Indonesia, Jakarta

Rachmawati, Intan (2015) Pengaruh Lingkungan Kerja Non Fisik Terhadap Kinerja Karyawan (Studi Kasus pada Dinas Pekerjaan Umum Kabupaten Ponorogo) Skripsi,Tesis, Universitas Muhammadiyah Ponorogo. Diakses dari website http//libraryumpo.ac.id
Diunduh pada 3 Nopember 2017

Rivai,Veithzal, 2004 Manajemen Sumber Daya Manusia Untuk Perusahaan Jakarta: Raja Grafindo Persada

Rivai,Veithzal, Jauvani Sagala, 2009 Manajemen Sumber Daya Manusia Perusahaan dari Teori ke Praktik, Jakarta PT. Raja Grafindo Persada

R. Damanik, 2015 Pengaruh Lingkungan Kerja Non Fisik Terhadap kinerja Karyawan (Studi Kasus pada PT. Bank Mandiri Syariah Cabang di Jalan Ir. H.Juanda Bandung) Diakses dari dari website http// repository.unhas, ac,id/handle. Diunduh pada 3 Nopember 2017

Siagian,Sondang, 2015 Manajemen Sumber Daya Manusia Edisi 1 Bumi Aksara, Jakarta

Sedarmayanti, 2001 Sumber Daya Manusia Dan Produktivitas Kerja Cetakan Kedua, Mandar Maju, Bandung

Umar,Husein, 2003 Riset Pemasaran Dan Perilaku Konsumen, PT. Gramedia Pustaka Utama bekerjasama dengan Jakarta Business Reseach Centre, Jakarta

Wibowo, 2010 Manajemen Kinerja Edisi Ketiga, PT. Raja Grafindo Persada Jakarta

Wursanto,Ignasius, 2003 Dasar-Dasar Ilmu Organisasi Penerbit Andi, Yogyakarta 